\title{
Genetic diversity of irrigated medium duration of rice genotypes suited for eastern plain zone of U.P.
}

\author{
Aishwarya Singh Rajput ${ }^{1}, \mathrm{G}$. Suresh Babu ${ }^{2}$ and Mahendra Bhatti ${ }^{3}$ \\ ${ }^{1,2,3}$ (Department of Genetics and Plant Breeding, Allahabad school of Agriculture, Sam Higginbottom Institute \\ of Agriculture, Technology and Sciences(Deemed-to-be-University), Allahabad-211007, U.P. India)
}

\begin{abstract}
The present investigation was conducted to examine the genetic diversity existing among 41 genotypes of rice, during kharif-2013 under randomized block design with three replications. The data were recorded for thirteen quantitative characters to obtain estimates of variability, heritability, genetic advance and genetic divergence. Significant differences were observed among the genotypes for all the characters studied. High estimates of GCV and PCV were observed for economic yield followed by harvest index and flag leaf length. High heritability coupled with high genetic advance was recorded for spikelets per panicle. Mahalanobis $D^{2}$ analysis revealed considerable amount of diversity in the material. The forty-one genotypes were grouped into seven heterogeneous clusters. Among these clusters, Cluster I had maximum number of genotypes (9). On the basis of mean performance genotypes CR 264-26-1-2-2 and RP 5213-69-13-3-4-1-2-B were found to be the best genotypes in Allahabad agro-climatic conditions. The characters such as grain yield, harvest index, number of panicles per plant and biological yield per plant should be given top priority for effective selection. The present investigation revealed that Cluster V and VII are most diverse to each other and the genotypes constituted in these clusters may be used as parents for future hybridization.
\end{abstract}

Keywords: $D^{2}$ analysis, Genetic advance, GCV, Heritability, PCV, Genetic diversity (Rice (Oryza sativa L.).

\section{Introduction}

More than 90 per cent of the world's rice is grown and consumed in Asia, known as rice bowl of the world, where 60 percent of the earth's people and two thirds of world's poor live. The world population is expected to reach eight billion by 2030 and rice production must increase by 50 per cent in order to meet the growing demand (Khush and Brar, 2002). Rice, being one of the important cereal crops of India, ranking first among all the cereal crops, is cultivated as pure culture mainly in wet season; cultivated in large area but characterized by poor productivity due to lack of high yielding stable varieties adaptable for different seasons and agroclimatic conditions at different parts of the country. The basic objective of this crop improvement programs is to realize a marked improvement in crop yield through various breeding methods. In order to step up the production potential, it is necessary to launch a dynamic breeding program to develop improved rice varieties suitable for different agro-climatic regions. For planning and execution of a successful breeding program, the most essential pre-requite is the availability of substantial desirable genetic variability for important characters in the germplasm collections of the plant species. The available variability in a population can be partitioned into genetic parameters such as coefficients of variation, heritability and genetic advance to serve as basis for selection of desirable genotypes than existing ones. Genetic diversity is an important tool for a crop improvement programme, as it helps in the development of superior recombinants (Manonmani and Fazlullah Khan 2003). Genetic divergences among the genotypes play an important role in selection of parents having wider variability for different traits (Nayak et al., 2004). The ultimate goal of any plant breeding programme is to develop improved genotypes which are better than the existing ones in producing the economic yield. This requires genetic amelioration through maximum utilization of allelic resources to develop ideal genotype.

\section{Materials And Methods}

The material for the present study comprised 41 rice germplasm accessions along with one check (NDR-359), evaluated in a randomized block design at Research Farm of Department of Genetics and Plant Breeding, SHIATS, Allahabad during wet season, 2013. Twenty six days old seedlings were transplanted in 2 $\mathrm{m}^{2}$ plots with $20 \mathrm{~cm} \times 15 \mathrm{~cm}$ spacing. All the standard cultural practices and packages were followed to raise a good and healthy crop. In each entry, five competitive plants were selected randomly, data recorded on thirteen traits viz., days to $50 \%$ flowering, plant height, flag leaf length, flag leaf width, number of tillers per plant, number of panicles per plant, panicle length, number of spikelets per panicle, days to maturity, biological yield per plant, harvest index, test weight and grain yield per plant. The analysis of variance was carried out for all the characters and then data was analyzed following multivariate analysis of Mahalanobis (1936) and genotypes were grouped into different clusters following Tocher's method (Rao, 1952). 


\section{Results And Discussion}

A wide range of variation was observed among 41 rice (Oryza sativa L.) genotypes for thirteen quantitative characters. The perusal of data revealed that variance due to treatment was highly significant for all the characters exhibited by the genotypes. Significant genetic variation in various component characters might be effective.

\section{Genetic Parameters}

The analysis of variance revealed significant difference among the genotypes for all the characters studied (Table 1). Close relationship between GCV and PCV was found in all the characters and PCV values were slightly greater than GCV, revealing very little influence of environment for their expression the high genotypic coefficient of variability (GCV) and phenotypic coefficient of variability (PCV) recorded for grain yield per plant followed by Flag leaf length and Harvest index. Similar finding found were Nayak et al. (2002) and Vivek et al. (2005). It indicates that the existence of wide spectrum of variability for these traits and offer greater opportunities for desired traits through phenotypic selection. High heritability coupled with high genetic advance was observed for number of spikelets/panicle, Biological yield/ hill and Plant height (Table 1). This indicates the lesser influence of environment in expression of these characters and prevalence of additive gene action in their inheritance hence, amenable of simple selection. The above mentioned two characters had high heritability with moderate genetic advance, indicating that the characters were also governed by both additive and non-additive gene actions. These results are accordance with Patil et al (2003), Elayaraja et al (2005) and Jayasudha and Sharma (2010).

\section{Genetic Divergence}

The 41 genotypes were grouped into 7 distinct clusters (Table 2). Among 7 clusters, cluster I was the largest with 9 genotypes, followed by cluster V and VII with 7 genotypes and cluster IV with 6 genotypes. Clustering pattern of genotypes showed lack of any relationship between geographic origin and genetic diversity reported by (Vivekanandan and Subramanian, 1993, Nayak et al., 2004). Maximum inter cluster distance was reported between cluster V and VII followed by cluster IV and VII and cluster VI and VII suggesting that the genotypes present in these clusters may be used as parents for hybridization programme to develop desirable type. To realize much variability and high heterotic effect, Pradhan and Roy, (1990); Mishra et al., (2003) and Chaturvedi and Maurya, (2005) recommended that parents should be selected from two clusters having wider inter cluster distance. The very high intra-cluster distance for cluster III (Table 3). The crossing between superior genotypes of above diverse cluster pairs may provide desirable transgressive segregants for developing high yielding varieties of rice. Intercrossing of divergent genotypes with desirable traits would lead to greater opportunity for maximum amount of heterosis and utilize them for multiple crossing programmes to accumulate favourable genes in single genotypes.

The selection and choice of parents mainly depends upon contribution of characters towards divergence (Nayak et al., 2004 and De and Suriya Rao, 1987). Contribution towards genetic divergence is presented in (Table 4). The highest contribution in manifestation of genetic divergence was exhibited by Spikelets/ panicle (64.02 percent), Biological yield/ hill (15.61 percent), and Flag leaf length (9.02 percent) showed $88.65 \%$ contribution towards total divergence, Pandey and John (2010) also reported that the characters Plant height and Test weight contributed maximum to divergence and should form the basis of selection for genotypes. In other words, selection for these characters may be rewarding.

\section{Conclusion}

The present study concluded that the genotype CR 264-26-1-2-2 and RP 5213-69-13-3-4-1-2-B recorded high yield among 41 rice genotypes evaluated under the study. High heritability and genetic advance observe in spikelets/ panicle, biological yield/ hill and plant height hence parameters could be used as for selection. The present investigation further revealed that cluster V and VII are most diverse to each other. Therefore, genotypes present in these clusters are suggested to provide a broad spectrum of variability in segregating generations and may be used as parents for future hybridization programme to develop desirable type.

\section{Acknowledgements}

We thank Dr. Suresh Babu Sir (senior scientist of SHIATS, Allahabad.) and Dr. G. R. Lavanya Mam (Assistant Professor of SHIATS, Allahabad.) James Sir (Form Manager) and All workers of Genetics and Plant Breeding Department SHIATS, Allahabad. For their excellent technical assistance. 
Genetic diversity of irrigated medium duration of rice genotypes suited for eastern plain zone of U.P.

Table 1: Genetic parameters for 13 biometrical characters of 41 rice genotypes.

\begin{tabular}{|c|l|c|c|c|c|c|c|c|}
\hline S. No. & \multicolumn{1}{|c|}{ Characters } & Vg & Vp & GCV & PCV & $\begin{array}{c}\mathrm{h}^{2} \\
\text { (broad } \\
\text { sense) }(\%)\end{array}$ & $\begin{array}{c}\text { GA } \\
\text { mean }\end{array}$ \\
\hline 1 & Day of 50\% flowering & 7.56 & 11.31 & 2.84 & 3.48 & 67 & 4.62 & 4.78 \\
\hline 2 & Plant height (cm) & 60.16 & 65.83 & 7.14 & 7.47 & 91 & 15.27 & 14.06 \\
\hline 3 & Flagleaf length (cm) & 20.63 & 21.74 & 15.18 & 15.59 & 95 & 9.11 & 30.47 \\
\hline 4 & Flagleaf width (cm) & 0.02 & 0.02 & 11.54 & 12.28 & 88 & 0.28 & 22.34 \\
\hline 5 & Tillers/plant & 3.38 & 4.40 & 12.75 & 14.55 & 77 & 3.31 & 23.01 \\
\hline 6 & Panicles/plant & 2.43 & 3.36 & 12.19 & 14.33 & 72 & 2.73 & 21.37 \\
\hline 7 & Panicle length (cm) & 4.90 & 5.62 & 8.54 & 9.14 & 87 & 4.25 & 16.44 \\
\hline 8 & Spikelets panicle & 795.29 & 799.67 & 11.69 & 11.72 & 99 & 57.93 & 24.01 \\
\hline 9 & Days to maturity & 6.66 & 9.86 & 2.04 & 2.48 & 68 & 4.37 & 3.45 \\
\hline 10 & Biological yield/ hill (g) & 147.66 & 154.00 & 13.77 & 14.06 & 96 & 24.51 & 27.77 \\
\hline 11 & Harvest index (\%) & 43.11 & 48.03 & 13.91 & 14.69 & 90 & 12.81 & 27.15 \\
\hline 12 & Test weight (g) & 4.82 & 5.49 & 8.95 & 9.55 & 88 & 4.23 & 17.27 \\
\hline 13 & Grain yield (g) & 44.44 & 48.22 & 16.06 & 16.72 & 88 & 13.18 & 31.75 \\
\hline
\end{tabular}

Table 2: Distribution of the 41 genotypes into different clusters

\begin{tabular}{|c|c|c|c|}
\hline S. No & Cluster numbers & Number of genotypes & Genotypes included \\
\hline 1 & I & 9 & $\begin{array}{l}\text { TM 07275, CRK 27, UPRI 2009-9, HKR 08-62, R 1582-814-1- } \\
\text { 258-1, ORJ-7, CR } 2706 \text { 9IR 84895-B-CRA-171-32, ORS-325, NP- } \\
124-8 .\end{array}$ \\
\hline 2 & II & 4 & IR-79478-15-2-2-2, IR-81852-15-2-2-3, VK-18, VK38. \\
\hline 3 & III & 5 & $\begin{array}{l}\text { NDR } 9479 \text { (IR 70174-14-SRN-4-UBN-2-B), CN 1740-5-3-3-2- } \\
\text { MLD 9, KAGR 426, HKR 07-147, TRC 2008-6. }\end{array}$ \\
\hline 4 & IV & 6 & $\begin{array}{l}\text { KMPN149, OR 2404-RKP-4, CN 1744-21-5-1-MLD 10, KAGR } \\
\text { 559-1, JGL 18065, R 1576-1700-1-560-1. }\end{array}$ \\
\hline 5 & $\mathrm{~V}$ & 7 & $\begin{array}{l}\text { LALAT (RC), RP 5213-69-13-3-4-1-2-B, CRR 624207-B-1-B, CN } \\
\text { 1446-5-8-17-1-MLD-4, R 78091-6-2-3-1-1, R 1528-1058-1-110-1, } \\
\text { R 1535-1382-1-1667-1. }\end{array}$ \\
\hline 6 & VI & 3 & OR 2324-25-1, UPR 3425-11-1-1, ORS-325. \\
\hline 7 & VII & 7 & $\begin{array}{l}\text { NP-6226, UPR 3528-12-1-12, NDR 370133, UPR 3413-8-2-1, } \\
\text { CR2644-2-6-4-3-2, CR264-26-1-2-2, NDR359 (CHEAK). }\end{array}$ \\
\hline
\end{tabular}

Table 3: Estimates of average intra (diagonal and bold) and inter cluster distances for 7 clusters in rice.

\begin{tabular}{|c|c|c|c|c|c|c|c|}
\hline & $\begin{array}{c}\text { Cluster } \\
\text { I }\end{array}$ & $\begin{array}{c}\text { Cluster } \\
\text { II }\end{array}$ & $\begin{array}{c}\text { Cluster } \\
\text { III }\end{array}$ & $\begin{array}{l}\text { Cluster } \\
\text { IV }\end{array}$ & $\begin{array}{c}\text { Cluster } \\
\mathrm{V}\end{array}$ & $\begin{array}{c}\text { Cluster } \\
\text { VI }\end{array}$ & $\begin{array}{c}\text { Cluster } \\
\text { VII }\end{array}$ \\
\hline Cluster I & 95.30 & 184.27 & 240.93 & 625.93 & 797.74 & 635.32 & 467.24 \\
\hline Cluster II & & 0.00 & 115.25 & 225.52 & 371.19 & 252.28 & 993.87 \\
\hline Cluster III & & & 105.23 & 222.46 & 300.13 & 237.62 & 936.09 \\
\hline Cluster IV & & & & 0.00 & 56.49 & 76.85 & 1819.58 \\
\hline Cluster V & & & & & 0.00 & 62.97 & 1950.29 \\
\hline Cluster VI & & & & & & 0.00 & 1733.20 \\
\hline Cluster VII & & & & & & & 0.00 \\
\hline
\end{tabular}


Table 4: Per cent contribution of each character towards genetic divergence in rice germplasm

\begin{tabular}{|l|l|c|}
\hline S. No. & \multicolumn{1}{|c|}{ Characters } & Contribution Percent \\
\hline 1 & Days to $50 \%$ flowering & 0.37 \\
\hline 2 & Plant height $(\mathrm{cm})$ & 5.85 \\
\hline 3 & Flag leaf length $(\mathrm{cm})$ & 9.02 \\
\hline 4 & Flag leaf width $(\mathrm{mm})$ & 0.61 \\
\hline 5 & Tillers/ plant & 1.34 \\
\hline 6 & Panicles/ plant & 0.00 \\
\hline 7 & Panicle length $(\mathrm{cm})$ & 0.85 \\
\hline 8 & Spikelets/ panicle & 64.02 \\
\hline 9 & Days to maturity & 0.00 \\
\hline 10 & Biological yield/ hill $(\mathrm{g})$ & 15.61 \\
\hline 11 & Harvest index $(\%)$ & 0.73 \\
\hline 12 & Test weight $(\mathrm{g})$ & 1.59 \\
\hline 13 & Grain yield $(\mathrm{g})$ & 0.00 \\
\hline
\end{tabular}

\section{References}

[1]. Chaturvedi, H.P., Maurya, D.M. 2005. Genetic divergence analysis in rice (Oryza sativa L.). Advances in Plant Sciences. 18(1): 349-353.

[2]. De, R. N. and Suriya Rao, A. V. 1987. Genetic divergence in rice under low land situation. Crop Improvement. 14(2): 16-21.

[3]. Elayaraja, K., Prakash M., Saravana, K., Kumar, B. S. and Ganesan, J. 2005. Studies on variability, heritability and genetic advance quantitative characters in rice (Oryza sativa L.). Crop Research. 29(1): 134-137.

[4]. Jayasudha, S. and Sharma, D. 2010. Genetic parameters of variability, correlation and path-coefficient for grain yield and physiological traits in rice (Oryza sativa L.) under shallow lowland situation. Electronic Journal of Plant Breeding. 1(5): 1332-1338.

[5]. Khush, G. S. \& Brar, D. S. 2002. Biotechnology for rice breeding: progress and impact. In: Sustainable rice production for food security. Proceedings of the 20th Session of the International Rice Commission. Bangkok, Thailand, July, 23-26.

[6]. Mahalanobis, P.C. 1936. On the generalized distance in statistics. Proceeding of National Institute of Sciences, India. 2: 49- 55.

[7]. Manonmani, S. and Fazlullah Khan, A. K. 2003. Analysis of genetic diversity for selection of parents in rice. Oryza, 40: 54-56.

[8]. Mishra L.K., Sarawgi, A.K. and Mishra, R.K. 2003. Genetic diversity for morphological and quality traits in rice (Oryza sativa L.). Advances in Plant Sciences. 16(1): 287-293.

[9]. Nayak, A.R., Chaudhury, D. and Reddy, J.N. 2002. Genetic variability, heritability and genetic advance in scented rice. Indian Journal of Agricultural Sciences. 46(12): 45-47.

[10]. Nayak, A. R., Chaudhury, D. and Reddy, J. N. 2004. Genetic divergence in scented rice.Oryza, 41: 79-82.

[11]. Pandey, P. and Johan A. 2010. Estimation of genetic parameters in indigenous rice. Advances in Agriculture \& Botanics. $2: 1$-79.

[12]. Patil, P. V., Sarawgi, A. K. and Shrivastava, M. N. 2003. Genetic analysis of yield and quality traits in traditional aromatic accessions of rice. Journal Maharashtra Agriculture University. 28(33): 255-258.

[13]. Pradhan, A.K. and Roy, A. 1990. Genetic divergence in rice. Oryza. 27(4): 415-418.

[14]. Rao, C.R. 1952. Advance statistical methods in Brometrical research. John Wiley and Sons, Increased. New York.

[15]. Thomas, N. and Lal, G.M. 2012. Genetic divergence in rice genotypes under irrigated conditions. Annals of Plant and Soil Research. 14(2): 109-112.

[16]. Vivek, S., Singh, S., Singh, S.K. and Singh, H. 2005. Estimation of genetic variability, heritability and genetic advance in rice (Oryza sativa L.). Agricultural Science Digest. 25(3): 207-209.

[17]. Vivekanandan, P. and Subramanian, S. 1993. Genetic divergence in rainfed rice. Oryza, 30: 60-62. 